ing their latest products in the Trade Section. The Research and Educational Section will contain contributions from research laboratories, and experiments of educational interest. In addition, the work submitted for the Craftsmanship and Draughtsmanship Competition by apprentices and learners will be on view. Discourses will be delivered at 7.45 on January 3 by Dr. J. D. Cockeroft, on "The Cyclotron and its Applications", and on January 4 by Mr. C. S. Wright, on "Geophysical Research in Polar Regions". Admission to the exhibition is by ticket only, obtainable from scientific societies or direct from the Exhibition Secretary, 1 Lowther Gardens, Exhibition Road, S.W.7.

\section{British Association: Dundee Meeting}

THE annual meeting of the British Association will be held next year in Dundee from August 30 until September 6 under the presidency of Sir Albert Seward. The following sectional presidents have been appointed: Section A (Mathematical and Physical Sciences), Mr. R. S. Whipple; Section B (Chemistry), Prof. E. K. Rideal ; Section C (Geology), Prof. H. H. Read; Section D (Zoology), Prof. J. Ritchie; Section E (Geography), Mr. A. Stevens; Section F (Economics), Prof. H. O. Meredith; Section G (Engineering), Mr. H. E. Wimperis; Section $H$ (Anthropology), Prof. W. E. Le Gros Clark ; Section I (Physiology), Prof. D. Burns ; Section J (Psychology), Mr. R. J. Bartlett; Section K (Botany), Prof. D. Thoday; Section L (Education), Dr. A. P. M. Fleming; Section M (Agriculture), Sir Thomas Middleton.

\section{Colonial Service Appointments}

THE following appointments and promotions in the Colonial Service have recently been made : J. E. R. Roe, veterinary officer, Uganda; T. Bell (Government Stock Farm and Agricultural Station, Acre, Palestine), agricultural superintendent, British Guiana; W. A. Gordon (assistant conservator of forests, Gold Coast), assistant conservator of forests, Cyprus ; G. W. St. Clair-Thompson (assistant conservator of forests, Gold Coast), assistant conservator of forests, Uganda; J. H. Gibbons (chief inspector of mines, Northern Rhodesia), senior inspector of mines, Tanganyika Territory; K. E. Lee (assistant inspector of mines, Uganda), inspector of mines, Federated Malay States; I. Humphrey (supervisor of physical training, Sierra Leone), meteorological assistant, Nigeria.

\section{Announcements}

SIR JoHN ForsDyke, director and principal librarian of the British Museum, and Mr. John L. Kirk, honorary director of the Castle Museum, York, have recently been elected honorary members of the Yorkshire Philosophical Society, York.

AT a reception on December 6 at the Belgian Embassy, Baron de Cartier de Marchienne, the Ambassador, presented a number of bronze medals awarded by King Leopold of the Belgians to various
British scientific workers. The medals, bearing on one side the head of King Leopold and on the other the name of the recipient, and the occasion of the award, were a token of appreciation for the help given by the various specialists in classifying the natural history collections which the King of the Belgians made in 1928-29 during his voyage to the East. The recipients, most of whom were present at the Embassy, were: Sir Guy Marshall, Dr. K. Jordan, Dr. Isabella Gordon, Dr. S. Maulik, Dr. W. H. Leigh-Sharpe, Miss G. Ricardo, Mr. C. L. Collenette, Mrs. L. M. I. Macfadyn, Mr. W. H. T. Tams, Mr. H. E. Andrewes, Miss I. Meyrick (for her late father, Mr. E. Meyrick), Prof. H. Gordon Jackson, Dr. H. Hanitsch, Mr. C. J. Arrow, Dr. Evelyn Cheesman, Dr. Marie V. Lebour, Dr. Schwarz, Mr. L. B. Prout, Mr. A. J. T. Janse and Lieut.-Colonel F. C. Fraser.

Dr. Irving LANGMUIR will deliver an address before the Physical Society on December 20 at 5.15. The subject of Dr. Langmuir's address will be "The Structure of Proteins".

AN industrial fellowship has been established in the Mellon Institute, Pittsburgh, by the American Air Filter Company, Inc., of Louisville, $\mathrm{Ky}$. This fellowship will aid investigations on materials of value in the construction of filters for air-conditioning systems. Dr. Frank F. Rupert, who has been appointed to the fellowship, has been a member of the Mellon Institute since 1913. Since 1935 he has been associated with the fellowship on air hygiene in the Institute.

UNDER the terms of administration of the Clough Memorial Research Fund of the Edinburgh Geological Society a sum of approximately $£ 30$ is available annually for the purpose of encouraging geological research in Scotland and the north of England. The north of England is defined as comprising the counties of Northumberland, Cumberland, Durham, Westmorland and Yorkshire. Applications for grants are invited for the period April 1, 1939-March 31, 1940, and should reach the Secretary, Clough Research Fund Committee, Edinburgh Geological Society, Synod Hall, Castle Terrace, Edinburgh, not later than February 1, 1939.

ThE fourth Oxford Farming Conference will be held at Oxford on January 3-5, under the auspices of the School of Rural Economy, the Agricultural Economics Research Institute and the Institute for Research in Agricultural Engineering of the University. The general theme of the Conference will be "The Business Organization of the Farm". Further information can be obtained from the Conference Secretary, 10 Parks Road, Oxford.

The Cambridge University Press will publish early in the New Year "A Short History of the Steam Engine", by Mr. H. W. Dickinson, formerly of the Science Museum, South Kensington. The author, it is stated, discusses not only the inventions, but also the inventors. 